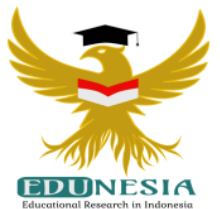

\title{
Motivasi Belajar dan Regulasi Diri Mahasiswa Selama Pandemi Covid-19
}

\author{
Sri Hardianti Sartika \\ Department of Economic Education, Siliwangi University, Indonesia \\ Corresponding Email : sri.hardianti@unsil.ac.id, Phone Number : 0852 xxxx xxxx
}

\section{Article History:}

Received: Dec 15, 2020

Revised: Dec 20, 2020

Accepted: Dec 21, 2020

Published: Jan 01, 2021

Keywords:

College student, Learning motivation, Self-regulated

Kata Kunci:

Mahasiswa, Motivasi

belajar, Regulasi diri

\section{How to cite:}

Sartika, H.S. (2021). Motivasi Belajar Dan Regulasi Diri Mahasiswa Selama Pandemi Covid-19. Edunesia: Jurnal Ilmiah Pendidikan, 2 (1): 260271

This is an open access article under the CC-BY-NC-ND license

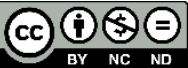

\begin{abstract}
During the Covid-19 Pandemic, learning motivation and selfregulation were identified as factors that influenced college student to involving in learn process. The research focus is to explain the objective conditions of learning motivation and self-regulation of college student during the pandemic. The reserach is a quantitative study with an interpretive approach involving 88 college student in $3^{\text {rd }}$ semester in Department of Economic Education at Siliwangi University, as participants. The data was collected by means of a survey in the form of a questionnaire that adopted the measuring instrument of learning motivation and self-regulation developed by Velayutham et al. The survey was carried out by distributing questionnaires in the form of googleform so that it was easily accessed by students. Data analysis uses the calculation of the percentage of each indicator and analyzes it in depth. The finding indicate that the condition of student learning motivation during the Covid-19 pandemic as measured by 3 indicators learning in goal orientation, task value and self-efficacy are in the excellent category with a score of $83 \%$. Self-regulation of college student in learning during the Covid-19 pandemic is in the excellent category or with a score of $81 \%$. The excellent categories of learning motivation and self-regulation describe that college students are able to adapt in pandemic emergency online learning.
\end{abstract}

\begin{abstract}
Abstrak: Pada masa Pandemi Covid-19, motivasi belajar dan regulasi diri diidentifikasi sebagai faktor yang mempengaruhi keterlibatan mahasiswa dalam pembelajaran. Fokus penelitian ini menjelaskan kondisi objektif motivasi belajar dan regulasi diri mahasiswa selama masa pandemi. Penelitian ini merupakan penelitian kuantitatif dengan pendekatan interpretative yang melibatkan 88 orang mahasiswa semester 3 pada Jurusan Pendidikan Ekonomi di Universitas Siliwangi, sebagai partisipan. Pengumpulan data dilakukan dengan cara survey berupa kuesioner yang mengadopsi instrumen pengukuran motivasi belajar dan regulasi diri yang dikembangkan oleh Velayutham dkk. Survey dilakukan dengan menyebarkan kuesioner berupa googleform agar mudah diakses oleh mahasiswa. Analisis data menggunakan perhitungan presentase dari setiap indikator dan menganalisisnya secara mendalam. Temuan ini menunjukan bahwa kondisi motivasi belajar mahasiswa selama pandemi Covid-19 yang diukur dengan tiga indikator yaitu, orientasi pada tujuan, nilai tugas dan efikasi diri termasuk kategori sangat tinggi dengan skor 83\%. Regulasi diri mahasiswa dalam pembelajaran selama masa pandemi Covid-19 tergolong pada kategori sangat tinggi atau dengan skor $81 \%$. Kategori motivasi belajar dan regulasi diri yang sangat tinggi tersebut menggambarkan bahwa mahasiswa mampu berdaptasi pada pembelajaran online darurat selama masa pandemi ini.
\end{abstract}




\section{A. Pendahuluan}

Covid-19 merupakan suatu virus yang dapat menyebabkan penyakit menular berupa infeksi saluran pernafasan manusia, berdasarkan data dari World Health Organization (WHO) kasus Covid-19 pertama kali terkonfirmasi di provinsi Wuhan Cina pada 31 Desember 2019 yang awalnya didiagnosis sebagai "pneumonia etiologi yang tidak diketahui" (Vicario-merino, 2020). Virus Covid-19 telah tersebar semakin luas diseluruh dunia, sehingga sejak 11 Maret 2020 WHO resmi menetapkan fenomena Covid-19 sebagai sebuah pandemi (World Health Organization, 2020). Sejak 2 Maret 2020 yaitu terkonfirmasinya kasus pertama di Indonesia hingga November 2020 telah terkonfirmasi sebanyak 538.883 kasus serta akan terus bertambah parah jika masyarakat tidak patuh pada protokol kesehatan yang telah ditetapkan pemerintah (Covid19.go.id, 2020). Pandemi Covid-19 menjadi persoalan multidimensi, khususnya dalam sektor pendidikan karena menyebabkan penurunan kualitas dalam hal pembelajaran (Sahu, 2020) dengan kata lain pandemi Covid-19 menyebabkan perubahan dramatis dalam hal pembelajaran dan pengajaran.

Pada Maret 2020, sektor Pendidikan di Indonesia melalui kemendikbud menetapkan study from home (SFH) sehingga penyelenggaraan pendidikan dilakukan dengan cara Belajar dari Rumah (BDR) atau sering disebut dengan istilah Pembelajaran Jarak Jauh (PJJ). Kebijakan tersebut merupakan respon pemerintah dalam pelaksanaan pendidikan selama penyebaran Coronavirus Disease (Covid-19). PJJ berlaku untuk semua tingkatan Pendidikan, dari mulai pendidikan dasar dan menengah maupun pendidikan tinggi. Pembelajaran jarak jauh adalah pembelajaran yang memanfaatkan jaringan internet untuk mendapatkan materi pembelajaran. Nakayama et al (2014) mengindikasikan perbedaan lingkungan belajar dan karakteristik individu merupakan faktor yang menyebabkan bahwa tidak semua mahasiswa akan sukses dalam pembelajaran online.

Aktifitas belajar dari rumah sangat mempengaruhi perasaan sosial individu sehingga menyebabkan penurunan yang kuat dalam interaksi sosial dengan sesama mahasiswa dan penurunan motivasi belajar yang dimiliki. Penurunan motivasi ini terkait dengan lebih sedikitnya waktu untuk belajar serta jarangnya menghadiri diskusi kelompok kecil daripada sebelum masa pandemi Covid-19 (Meeter et al., 2020). Motivasi sebagai faktor kritis yang mempengaruhi pembelajaran online (Harandi, 2015), sehingga penerapan pembelajaran jarak jauh membutuhkan perhatian yang serius. Lingkungan pembelajaran online mengacu pada "setiap pengaturan yang menggunakan Internet untuk menyampaikan beberapa bentuk pengajaran kepada peserta didik secara terpisah oleh waktu, jarak, atau keduanya" (Dempsey \& Van Eck, 2020). Mullen \& Tallent-Runnels (2006) dalam studi tentang persepsi mahasiswa, menemukan bahwa siswa dikelas online membutuhkan dukungan dan memiliki tuntutan yang berbeda terkait motivasi, kepuasan terhadap mata kuliah dan belajar jika dibandingkan dengan siswa dalam pembelajaran tatap muka.

Motivasi belajar adalah dorongan yang dimiliki individu untuk belajar, bekerja keras dan berprestasi dalam bidang akademik. Shabani (2012) menganggap motivasi belajar sebagai suatu keyakinan yang melekat pada individu untuk membimbing tujuan pembelajaran, mendorong upaya berkelanjutan dalam perilaku belajar, memperkuat kognisi, serta meningkatkan hasil belajar. Koff \& Mullis (2011) mengangap bahwa motivasi belajar sebagai niat atau keinginan untuk berpartisipasi dalam melakukan upaya pembelajaran yang dilakukan atas pilihan kegiatan khusus serta upaya untuk kegiatan 
tersebut. Komponen motivasi belajar secara konsisten dikaitkan dengan motivasi adaftif yaitu orientasi tujuan pembelajaran, nilai tugas, dan efikasi diri, yang masing-masing merupakan bagian integral dari kesuksesan keterlibatan dalam pembelajaran mandiri (Zimmerman, 2002). Motivasi belajar merupakan permasalahan yang perlu disoroti dalam Pendidikan tinggi, terutama karena pentingnya pencapaian akademik dalam kehidupan profesional mereka.

Regulasi diri merupakan aspek yang harus dimiliki dalam pembelajaran online karena berhubungan dengan motivasi dan perilaku yang dapat dikendalikan oleh pelajar online (Lee \& Choi, 2011; Shea, 2010). Kemampuan untuk mengatur diri sendiri penting bagi siswa di tingkat mana pun terutama bagi mereka yang berada di perguruan tinggi karena dihadapkan dengan banyak materi dalam rentang waktu yang singkat (Cohen, 2012). Regulasi diri melibatkan upaya siswa untuk mengelola proses pembelajaran sistematis yang berorientasi untuk mencapai tujuan (Schunk \& Zimmerman, 2011). Regulasi diri menajdi sebuah tantangan bagi siswa dalam sebuah lingkungan belajar yang dimediasi teknologi terutama dalam lingkungan belajar online karena kemungkinan kurangnya dukungan dan merasa terisolasi secara sosial (Cho \& Shen, 2013). Hasil penelitian lain dari Cho dan Sen (2013) menunjukan bahwa adanya hubungan regulasi diri dan prestasi akademik mahasiswa selama pembalajarn jarak jauh. Peverly et.al (2003) menemukan bahwa sebagian besar mahasiswa dalam pembelajaran online memiliki regulasi diri yang rendah.

Motivasi belajar dan regulasi diri merupakan aspek yang penting dalam pembelajaran terutama selama PJJ pada masa pandemi ini. Pada pembelajaran online selama PJJ darurat, mahasiswa dituntut untuk mampu mengatur, mengarahkan, menyesuaikan serta mengendalikan diri sendiri dalam mengahadapi tugas akdemik yang ada. Penelitian ini mendefinisikan motivasi belajar sebagai proses dimana kegiatan yang dilakukan sesuai dengan tujuan yang dimiliki. Sedangkan konsep dari regulasi diri dalam penelitian ini adalah kemampuan mahasiswa untuk dapat menetapkan tujuan pembelajaran sendiri, menentukan konten dan kemajuan, memilih keterampilan dan metode, memantau keseluruhan proses serta melakukan pengaturan belajar secara mandiri. Selama pandemi Covid-19, PJJ menjadi metode pembelajaran utama tetapi keefktifan pembelajarannya masih harus diteliti lebih lanjut. Mahasiswa harus mampu mengontrol kegiatan belajarnya sehingga pembelajaran PJJ melalui tatap maya dapat berjalan maksimal. Penelitian ini dilakukan dengan tujuan memberikan gambaran secara objektif mengenai motivasi belajar dan regulasi diri yang dimiliki mahasiswa pada masa Pandemi Covid-19.

\section{B. Metode}

Penelitian ini menggunakan metode penelitian kuantitatif dengan pendekatan interpretative. Babones (2016) menyatakan bahwa penelitian kuantitatif interpretative yaitu statistik digunakan untuk menjelaskan hal-hal yang tidak dapat diamati. Prinsip utama metodologi kuantitatif interpretatif adalah triangulasi hasil penelitian yang diperoleh dengan menganalisis data dari beberapa perspektif, integrasi pengukuran dan pemodelan ke dalam proses penemuan yang lebih holistic dan kebutuhan untuk berpikir secara refleks tentang cara adanya data masuk. Penelitian kuantitatif interpretatif berpotensi menghasilkan hasil yang lebih banyak memiliki makna, mudah dipahami, dan dapat diterapkan. 
Penelitian ini melibatkan 88 orang mahasiswa semester 3 Jurusan Pendidikan Ekonomi, Universitas Siliwangi, Tasikmalaya. Fokus penelitian ini untuk menjelaskann kondisi objektif mengenai motivasi belajar dan regulasi diri mahasiswa selama pembelajaran online di masa pandemi Covid-19. Pengumpulan data dilakukan dengan cara survey berupa kuesioner yang mengadopsi instrumen pengukuran motivasi belajar dan regulasi diri yang dikembangkan oleh Velayutham et al (2011). Total pernyataan instrumen tersebut adalah 32 item dengan penskoran 5 poin menggunakan Likert Type Scale dengan $1=$ sangat tidak setuju dan $5=$ sangat setuju. Survey dilakukan dengan menyebarkan kuesioner berupa googleform agar mudah diakses oleh mahasiswa. Analisis data menggunakan perhitungan presentase dari setiap indikator dan menganalisisnya secara mendalam. Adapun cara menghitung presentase skor, sebagai berikut:

$$
\text { Rumus Index } \%=\frac{T \times P n}{Y} \times 100
$$

Gambar 1. Rumus Presentase Skor Responden

\section{Keterangan}

$\mathrm{T} \quad$ : Total jumlah responden yang memilih

Pn : Pilihan angka skor Likert

Y : Skor ideal

Hasil presentase yang telah diperoleh kemudian diinterpretasi berdasarkan tabel interval skor berikut ini :

Tabel 1. Kriteria Interpretasi Skor

\begin{tabular}{cc}
\hline Presentase & Keterangan \\
\hline $0 \%-19,99 \%$ & Sangat Rendah \\
\hline $20 \%-39,99 \%$ & Rendah \\
\hline $40 \%-59,99 \%$ & Sedang \\
\hline $60 \%-79,99 \%$ & Tinggi \\
\hline $80 \%-100 \%$ & Sangat Tinggi \\
\hline
\end{tabular}

Hasil perhitungan interpretasi skor, menjadi dasar acuan dalam melakukan analisis secara mendalam dan menyimpulkan bagaimana kondisi motivasi belajar dan regulasi diri mahasiswa selama masa pandemi Covid-19.

\section{Hasil dan Pembahasan}

Penelitian dilakukan untuk memberikan gambaran motivasi belajar dan regulasi diri mahasiswa selama Pandemi Covid 19. Penelitian ini melibatkan 88 orang mahasiswa semester 3 jurusan Pendidikan Ekonomi di Universitas Siliwangi, yang terdiri dari 70 orang perempuan dan 18 orang laki-laki dengan cara survey melalui kuesioner. Adapun hasil dari survey yang telah dilakukan dapat dijelaskan pada tabel dibawah ini : 
Tabel 2. Hasil Survey Motivasi Belajar dan Regulasi Diri pada Mahasiswa

\begin{tabular}{|c|c|c|c|}
\hline Indikator & Aspek & Presentase & Kriteria \\
\hline \multirow{8}{*}{$\begin{array}{l}\text { Orientasi } \\
\text { Tujuan } \\
\text { Pembelajaran }\end{array}$} & Belajar sebanyak yang dimampu & $86 \%$ & Sangat tinggi \\
\hline & $\begin{array}{l}\text { Mempelajari perkembangan } \\
\text { Pendidikan ekonomi }\end{array}$ & $82 \%$ & Sangat tinggi \\
\hline & $\begin{array}{l}\text { Tujuan untuk menguasai ilmu } \\
\text { keterampilan baru }\end{array}$ & $87 \%$ & Sangat tinggi \\
\hline & $\begin{array}{l}\text { Memahami pembelajaran yang } \\
\text { dilakukan }\end{array}$ & $91 \%$ & Sangat tinggi \\
\hline & $\begin{array}{l}\text { Mempelajari konten } \\
\text { pembelajaran yang diajarkan }\end{array}$ & $88 \%$ & Sangat tinggi \\
\hline & $\begin{array}{l}\text { Meningkatkan kemampuan } \\
\text { keterampilan pembelajaran }\end{array}$ & $90 \%$ & Sangat tinggi \\
\hline & $\begin{array}{l}\text { Memahami apa itu diajarkan } \\
\text { kepada saya }\end{array}$ & $91 \%$ & Sangat tinggi \\
\hline & $\begin{array}{l}\text { Memahami ide-ide ekonomi itu } \\
\text { penting }\end{array}$ & $85 \%$ & Sangat tinggi \\
\hline \multirow[t]{8}{*}{ Nilai Tugas } & $\begin{array}{l}\text { Pembelajaran yang ada dapat } \\
\text { digunakan dalam kehidupan } \\
\text { sehari-hari }\end{array}$ & $86 \%$ & Sangat tinggi \\
\hline & $\begin{array}{l}\text { Pembelajaran ekonomi yang } \\
\text { dipelajari menarik }\end{array}$ & $80 \%$ & Sangat tinggi \\
\hline & $\begin{array}{l}\text { Pembelajaran ekonomi yang } \\
\text { dipelajari berguna untuk saya } \\
\text { ketahui }\end{array}$ & $89 \%$ & Sangat tinggi \\
\hline & $\begin{array}{l}\text { Pembelajaran ekonomi dinilai } \\
\text { bermanfaat }\end{array}$ & $91 \%$ & Sangat tinggi \\
\hline & $\begin{array}{l}\text { Pembelajaran ekonomi relevan } \\
\text { bagi diri sendiri }\end{array}$ & $84 \%$ & Sangat tinggi \\
\hline & $\begin{array}{l}\text { Materi ekonomi memiliki nilai } \\
\text { praktis }\end{array}$ & $79 \%$ & Tinggi \\
\hline & $\begin{array}{l}\text { Pembelajaran ekonomi } \\
\text { memuaskan rasa ingin tahu }\end{array}$ & $83 \%$ & Sangat tinggi \\
\hline & $\begin{array}{l}\text { Pembelajaran ekonomi } \\
\text { mendorong untuk berpikir }\end{array}$ & $85 \%$ & Sangat tinggi \\
\hline \multirow[t]{3}{*}{ Efikasi Diri } & $\begin{array}{l}\text { Menguasai keterampilan yang } \\
\text { diajarkan }\end{array}$ & $73 \%$ & Tinggi \\
\hline & $\begin{array}{l}\text { Memikirkan bagaimana } \\
\text { melakukan pekerjaan sulit }\end{array}$ & $77 \%$ & Tinggi \\
\hline & $\begin{array}{l}\text { Berusaha mempelajari materia } \\
\text { ekonomi yang ada, walaupun } \\
\text { mengharuskan untuk bekerja } \\
\text { keras }\end{array}$ & $79 \%$ & Tinggi \\
\hline
\end{tabular}




\begin{tabular}{lllc}
\hline Indikator & \multicolumn{1}{c}{ Aspek } & Presentase & Kriteria \\
\hline & $\begin{array}{l}\text { Mampu menyelesaikan } \\
\text { pekerjaan sulit jika saya } \\
\text { mencoba }\end{array}$ & $83 \%$ & Sangat tinggi \\
\hline \begin{tabular}{l} 
Keyakinan menerima nilai bagus \\
\cline { 2 - 4 }
\end{tabular} & $\begin{array}{l}\text { Kemampuan mempelajari } \\
\text { matakuliah yang dilakukan }\end{array}$ & $72 \%$ & Sangat tinggi \\
\hline & $\begin{array}{l}\text { Keyakinan memahami isi yang } \\
\text { diajarkan }\end{array}$ & $74 \%$ & Tinggi \\
\hline $\begin{array}{l}\text { Keyakinan diri bahwa ahli } \\
\text { dalam hal materi ekonomi }\end{array}$ & $65 \%$ & Tinggi \\
\hline Regulasi Diri & $\begin{array}{l}\text { Tetap mengerjakan ketika tugas } \\
\text { tidak menarik }\end{array}$ & $85 \%$ & Sangat tinggi \\
\hline $\begin{array}{l}\text { Bekerja keras bahkan jika tidak } \\
\text { menyukai apa yang saya } \\
\text { lakukan }\end{array}$ & $\begin{array}{l}\text { Belajar meskipun ada hal yang } \\
\text { lebih baik untuk dilakukan }\end{array}$ & $72 \%$ & Sangat tinggi \\
\hline $\begin{array}{l}\text { Berkonsentrasi agar tidak } \\
\text { ketinggalan poin penting }\end{array}$ & $\begin{array}{l}\text { Menyelesaikan pekerjaan dan } \\
\text { tugas tepat waktu }\end{array}$ & $85 \%$ & Tinggi \\
\hline $\begin{array}{l}\text { Tidak menyerah bahkan saat } \\
\text { bekerja sulit }\end{array}$ & $\begin{array}{l}\text { Serkonsentrasi di kelas } \\
\text { Bengerjakan tugas hingga beres }\end{array}$ & $87 \%$ & Sangat tinggi \\
\hline Mengi \\
\hline
\end{tabular}

Motivasi belajar mahasiswa memainkan peranan penting dalam proses pembelajaran karena motivasi belajar akan mendorong mahasiswa untuk belajar, bekerja keras dan berprestasi dalam bidang akademik. Pada penelitian ini motivasi belajar mahasiswa dapat dilihat berdasarkan tiga indikator yaitu orientasi tujuan, niilai tugas, serta efikasi diri. Indikator yang pertama yaitu berkaitan dengan orientasi tujuan pembelajaran yang dilakukan. Tabel 2 menunjukan bahwa beberapa aspek dari orientasi tujuan pembelajaran yang dimiliki oleh mahasiswa diantaranya adalah 1) belajar sebanyak yang dimampu dengan skor presentase $86 \%$ termasuk kriteria sangat tinggi, 2) mempelajari perkembangan pembelajaran mengenai pendidikan ekonomi dengan skor presentase $82 \%$ termasuk kriteria sangat tinggi, 3) tujuan untuk menguasai ilmu keterampilan baru dengan skor presentase $87 \%$ termasuk kriteria sangat tinggi, 4) memahami pembelajaran yang dilakukan dengan skor presentase 91\% termasuk kriteria sangat tinggi, 5) mempelajari konten pembelajaran yang diajarkan dengan skor presentase $88 \%$ termasuk kriteria sangat tinggi, 6) meningkatkan kemampuan keterampilan pembelajaran dengan skor presentase $90 \%$ termasuk kriteria sangat tinggi, 7) memahami apa itu diajarkan kepada saya dengan skor presentase $91 \%$ termasuk kriteria sangat tinggi, serta 8) memahami ide-ide ekonomi itu penting dengan skor presentase $85 \%$ termasuk kriteria sangat tinggi. 
Pembelajaran online selama Covid-19 menginterpretasikan bahwa peran kunci dari orientasi tujuan pembelajaran dalam motivasi belajar mengacu pada sejauh mana mahasiswa mengagngap dirinya berpartisipasi selama pembelajaran, memahami dan menguasai konsep pembelajaran mengenai materi pendidikan dan ekonomi serta mampu meningkatkan keterampilan dalam bidang ekonomi. Penelitian ini menemukan bahwa pada masa pandemi tidak merubah kegiatan mahasiswa untuk tetap belajar semaksimal mungkin dan tetap mempelajari perkembangan yang ada terutama mengenai situasi dan kondisi dalam bidang pendidikan maupun ekonomi, karena tujuan yang mereka miliki merupakan alasan mereka dalam mengikuti pembelajaran walaupun dilakukan secara tatap maya. Mahasiswa menganggap dirinya harus menguasai dan memahami konten pembelajaran yang diberikan dosen. Pintrich (2000) menemukan bahwa orientasi tujuan pembelajaran memberikan perspektif penting untuk membantu menjelaskan alasan keterlibatan mahasiswa dalam mengerjakan tugas. Menurut Ames dan Archer (1988) dalam teori pencapaian tujuan, ada dua jenis orientasi tujuan yaitu orientasi tujuan pembelajaran yang mengacu pada tujuan pengembangan kompetensi dan fokus pada belajar, memahami, dan menguasai tugas serta orientasi tujuan kinerja yang mengacu pada tujuan mendemonstrasikan kompetensi, khususnya dalam mengelola kesan orang lain.

Indikator kedua dalam motivasi belajar adalah nilai tugas, secara umum merupakan pandangan mahasiswa terhadap tugas atau materi yang diberikan selama pembelajaran. Nilai tugas yang dimiliki mahasiswa dari setiap aspek pengukuran diantaranya adalah 1) pembelajaran yang ada dapat digunakan dalam kehidupan sehari-hari dengan skor presentase $86 \%$ termasuk kriteria sangat tinggi, 2) pembelajaran yang dipelajari menarik dengan skor presentase $80 \%$ termasuk kriteria sangat tinggi, 3) pembelajaran ekonomi yang dipelajari berguna untuk diketahui dengan skor presentase $89 \%$ termasuk kriteria sangat tinggi, 4) pembelajaran ekonomi dinilai bermanfaat dengan skor presentase $91 \%$ termasuk kriteria sangat tinggi, 5) pembelajaran ekonomi relevan bagi diri sendiri dengan skor presentase $84 \%$ termasuk kriteria sangat tinggi, 6) materi ekonomi memiliki nilai praktis dengan skor presentase $79 \%$ termasuk kriteria tinggi, 7) pembelajaran ekonomi memuaskan rasa ingin tahu dengan skor presentase $83 \%$ termasuk kriteria sangat tinggi, serta 8) pembelajaran ekonomi mendorong untuk berpikir dengan skor presentase $85 \%$ termasuk kriteria sangat tinggi.

Nilai tugas merupakan komponen kunci motivasi belajar mahasiswa, terutama selama pembelajaran online dalam PJJ darurat masa pandemi Covid-19. Nilai tugas meinterpretasikan bahwa sejauh mana mahasiswa mempresepsikan pembelajaran dalam bidang pendidikan ekonomi sebagai salah satu minat, kepentingan dan kegunaan. Penelitian ini menggambarkan bahwa pembelajaran online darurat selama pandemi Covid19 terutama dalam bidang pendidikan dan ekonomi dianggap menarik karena bisa diimplemetasikan dalam kehidupan sehari-hari. Presepsi mahasiswa terhadap tugas akademik yang ada mampu mempertahankan motivasi belajar walaupun dalam keadaan pembelajaran online secara darurat. Eccles \& Wigfield (2002) menekankan peran integral dari nilai tugas untuk harapan dan pilihan yang berhubungan dengan prestasi, dan kinerja. Rosenthal dan Wolters (2000) mengemukakan bahwa secara teoritis keyakinan mahasiswa dalam memandang kegiatan belajar mereka itu penting, menarik, dan bermanfaat akan mendorong untuk menyelesiakan aktivitasnya. Selanjutnya, bahkan ketika rendahnya efikasi diri yang dimiliki mahasiswa, mereka akan cenderung untuk memulai dan 
mempertahankan upaya mereka jika mereka menghargai aktivitas belajarnya (Schunk \& Zimmerman, 2007).

Indikator ketiga dari motivasi belajar mahasiswa adalah efikasi diri dengan hasil rincian setiap aspek sebagai berikut 1) menguasai keterampilan yang diajarkan dengan skor presentase $73 \%$ termasuk kriteria tinggi, 2) memikirkan bagaimana melakukan pekerjaan sulit dengan skor presentase $77 \%$ termasuk kriteria tinggi, 3) berusaha mempelajari materia ekonomi yang ada, walaupun mengharuskan untuk bekerja keras dengan skor presentase $79 \%$ termasuk kriteria tinggi, 4) mampu menyelesaikan pekerjaan sulit jika berusaha mencoba dengan skor presentase $83 \%$ termasuk kriteria sangat tinggi, 5) keyakinan diri akan menerima nilai bagus dengan skor presentase $83 \%$ termasuk kriteria sangat tinggi, 6) kemampuan mempelajari matakuliah yang dilakukan dengan skor presentase $72 \%$ termasuk kriteria tinggi, 7) keyakinan memahami isi yang diajarkan dengan skor presentase $74 \%$ termasuk kriteria tinggi, serta 8) keyakinan diri bahwa ahli dalam hal materi ekonomi dengan skor presentase $65 \%$ termasuk kriteria tinggi.

Efikasi diri adalah prediktor kuat dari pilihan yang dibuat mahasiswa sebagai upaya yang dilakukan dan kegigihan dalam menghadapi kesulitan. Hasil survey dalam penelitian ini menunjukan bahwa presentase skor yang didapat pada aspek efikasi diri lebih kecil jika dibanding dengan kedua aspek motivasi lainnya, walaupun presentase skor yang ada masih dalam kategori tinggi. Pembelajaran yang dilakukan selama PJJ ini tidak memungkinkan mahasiswa untuk bertatap muka langsung dengan dosen, namun hanya dilakukan dengan tatap maya sehingga pembelajaran yang ada tidak berjalan secara maksimal, serta merupakan salah satu konsekuensi dari adanya PJJ darurat selama masa pandemi. Hal ini sejalan dengan Meeter (2020) bahwa perkuliahan online tidak seperti Pendidikan yang nyata.

Efikasi diri mahasiswa selalu dipengaruhi oleh efek lingkungan, kognitif dan perilaku yang terjadi dalam kehidupan sehari-hari. Shea dan Bidjerano (2010) menemukan bahwa semakin tinggi efikasi diri akademik maka semakin besar kemungkinan siswa untuk melakukannya mengatur upaya mereka dalam lingkungan pembelajaran online. Selanjutnya menurut Parajes (2002) efikasi diri terkait erat dengan pembelajaran mandiri. Schunk \& Pajares (2005) menambahkan bahwa tingkat efikasi diri yang sedang atau tinggi lebih cenderung untuk berusaha secara konsisten mengevaluasi kemajuan belajar dan menerapkan strategi pengaturan diri. Singkatnya, efikasi diri adalah konstruksi penting yang dapat mempengaruhi keterlibatan mahasiswa dalam pembelajaran.

Hasil analisis yang ada mengenai motivasi belajar mahasiswa selama masa pandemi Covid-19 menunjukan presentase skor rata-rata 83\% termasuk dalam kategori sangat tinggi. Sehingga dapat digambarkan bahwa motivasi belajar mahasiswa pada jurusan Pendidikan Ekonomi Universitas Siliwangi masih sangat tinggi walaupun pembelajaran yang ada berubah dari pembelajaran tatap muka langsung menjadi pembelajaran tatap maya.

Selain motivasi belajar, faktor yang berpengaruh dalam pembelajran online selama PJJ darurat masa pandemi Covid-19 adalah regulasi diri. Penelitian ini mengartikan regulasi diri sebagai kecenderungan untuk mempertahankan fokus dan usaha menuju tujuan meskipun potensi gangguan. Indikator regulasi diri menggunakan delapan aspek dengan hasil sebagai berikut 1) tetap mengerjakan ketika tugas tidak menarik dengan skor presentase $85 \%$, 2) bekerja keras bahkan jika tidak menyukai apa yang saya lakukan dengan skor presentase $81 \%$ termasuk kriteria sangat tinggi, 3) belajar meskipun ada hal yang lebih 
baik untuk dilakukan dengan skor presentase 72\% termasuk kriteria tinggi, 4) berkonsentrasi agar tidak ketinggalan poin penting dengan skor presentase $85 \%$ termasuk kriteria sangat tinggi, 5) menyelesaikan pekerjaan dan tugas tepat waktu dengan skor presentase $86 \%$ termasuk kriteria sangat tinggi, 6) tidak menyerah bahkan saat bekerja sulit dengan skor presentase $80 \%$ termasuk kriteria sangat tinggi, 7) berkonsentrasi di kelas dengan skor presentase $75 \%$ termasuk kriteria tinggi, serta 8) mengerjakan tugas hingga beres dengan skor presentase $87 \%$ termasuk kriteria sangat tinggi.

Temuan penelitain ini menganai regulasi diri yang dimiiki oleh mahasiswa menunjukan bahwa pola belajar mahasiswa selama masa pandemi bergantung pada orientasi tujuan mereka. Mahasiswa akan tetap mengerjakan tugas akademik walaupun banyak hal lainnya yang dianggap lebih menarik, dikarenakan kuatnya orientasi tujuan belajar yang dimiliki oleh mahasiswa. Selama proses pembelajaran online berlangsung atau selama tatap maya pembelajaran, mahasiswa tetap berkonsentrasi agar dapat menyimak materi pembelajaran secara utuh. Zimmerman (2008) menyatakan bahwa regulasi diri menilai sejauh mana siswa memiliki motivasi dan melakukan partisipasi dalam proses pembelajaran. Tujuan utama dari pembelajaran mandiri adalah bahwa pelajar mengarahkan proses kognitif dan motivasinya untuk mencapai tujuan pembelajaran. Fase siklus Zimmerman (2002) menyoroti peran utama regulasi diri sebagai keyakinan motivasi diri dalam memulai dan mempertahankan pengaturan diri dalam belajar. Zimmerman (2008) mengulangi bahwa persyaratan inti dari regulasi diri adalah inisiatif pribadi, ketekunan, dan keterampilan adaptif. Oleh karena itu, mahasiswa tidak hanya harus dimotivasi melalui menetapkan tujuan dan nilai pada aktivitas pembelajaran, tetapi juga menopang usaha sampai penyelesaian tugas (Boekaerts \& Cascallar, 2006). Hasil analisis dari delapan aspek mengenai regulasi diri pada mahasiswa jurusan Pendidikan Ekonomi Universitas Siliwangi menunjukan presentase rata-rata sebesar $81 \%$ atau termassuk kategori sangat tinggi. Hal ini menunjukan bahwa pandemi Covid-19 serta keadaan pembelajaran darurat secara online tidak menyurutkan regulasi diri mahasiswa dalam bildang akademik.

\section{Kesimpulan}

Hasil analisis menunjukan bahwa tiga indikator motivasi belajar mahasiswa yaitu orientasi tujuan pembelajaran, nilai tugas dan efikasi diri menunjukan skor rata-rata sebesar $83 \%$ termasuk dalam kategori sangat tinggi. Hasil yang sama ditunjukan oleh regulasi diri yang dimiliki mahasiswa berdasarkan presentase skor yaitu $81 \%$ atau masuk dalam kategori sangat tinggi. Kategori motivasi belajar dan regulasi diri tersebut menggambarkan bahwa mahasiswa mampu berdaptasi pada pembelajaran online darurat selama masa pandemic ini. Penelitian ini diharapakan dapat menjadi bahan kajian peneliti lain serta memberikan implikasi startegi pembelajaran online yang dapat diterapkan khususnya selama masa pandemic, yaitu berkaitan dengan motivasi belajar serta regulasi diri khususnya pada pembelajaran di Pendidikan tinggi.

\section{Daftar Pustaka}

Ames, C., \& Archer, J. (1988). Achievement Goals in the Classroom: Students' Learning Strategies and Motivation Processes. Journal of Educational Psychology, 80(3), 260-267. https://doi.org/10.1037/0022-0663.80.3.260 
Babones, S. (2016). Interpretive Quantitative Methods for the Social Sciences. Sociology, 50(3), 453-469. https:// doi.org/10.1177/0038038515583637

Boekaerts, M., \& Cascallar, E. (2006). How far have we moved toward the integration of theory and practice in self-regulation? Educational Psychology Review, 18(3), 199-210. https://doi.org/10.1007/s10648-006-9013-4

Cho, M. H., \& Shen, D. (2013). Self-regulation in online learning. Distance Education, 34(3), 290-301. https:/ / doi.org/10.1080/01587919.2013.835770

Cohen, M. (2012). The Importance of Self-Regulation for College Student Learning. College Student Journal, 46(1), 892-902. https://www.ingentaconnect.com/content/prin/csj/2012/00000046/00000004/ar t00018

Covid19.go.id. (2020). Infografis COVID-19 (30 November 2020). Covid19.Go.Id. https://covid19.go.id/p/berita/infografis-covid-19-30-november-2020

Dempsey, J., \& Van Eck, R. (2020). Instructional design on-line: Evolving expectations. Trends and Issues in Instructional Design and Technology, 281-294. https://www.researchgate.net/publication/285480554_Instructional_design_online_Evolving_expectations

Eccles, J. S., \& Wigfield, A. (2002). Motivational Beliefs, Values and Goals. Annual Review of Psychology, 53(1), 109-132. https://doi.org/10.1146/annurev.psych.53.100901.135153

Harandi, S. R. (2015). Effects of e-learning on Students' Motivation. Procedia - Social and Behavioral Sciences, 181(May), 423-430. https://doi.org/10.1016/j.sbspro.2015.04.905

Koff, L., \& Mullis, R. (2011). Nutrition Education and Technology: Can Delivering Messages via New Media Technology Effectively Modify Nutrition Behaviors of Preschoolers and Their Families? Journal of Nutrition Education and Behavior, 43(4), S40. https://doi.org/10.1016/j.jneb.2011.03.120

Lee, Y., \& Choi, J. (2011). A review of online course dropout research: Implications for practice and future research. Educational Technology Research and Development, 59(5), 593-618. https:/ / doi.org/10.1007/s11423-010-9177-y

Meeter, M., Den Hartogh, C. F., Bakker, T., De Vires, R. E., \& Plak, S. (2020). College students ' motivation and study results after COVID-19 stay-at- home orders. Vrije Universiteit Amsterdam.

Mullen, G. E., \& Tallent-Runnels, M. K. (2006). Student outcomes and perceptions of 
instructors' demands and support in online and traditional classrooms. Internet and Higher Education, 9(4), 257-266. https://doi.org/10.1016/j.iheduc.2006.08.005

Nakayama, M., Mutsuura, K., \& Yamamoto, H. (2014). Impact of learner's characteristics and learning behaviour on learning performance during a fully online course. Electronic Journal of E-Learning, 12(4), 394-408.

Parajes, F. (2002). Gender and perceived self-efficacy in self-regulated learning. Theory Into Practice, 41(2), 116-125.

Peverly, S. T., Brobst, K. E., Graham, M., \& Shaw, R. (2003). College adults are not good at self-regulation: A study on the relationship of self-regulation, note taking, and test taking. Journal of Educational Psychology, 95(2), 335-346. https:/ / doi.org/10.1037/0022-0663.95.2.335

Pintrich, P. R. (2000). The Role of Goal Orientation in Self-Regulated Learning. In Handbook of Self-Regulation (pp. 451-502). Elsevier. https://doi.org/10.1016/b978-0121098902/50043-3

Rosenthal, H., \& Wolters, C. A. (2000). The relation between students motivational beliefs and their use of motivational regulation strategies. International Journal of Educational Research, 33, 801-820.

Sahu, P. (2020). Closure of Universities Due to Coronavirus Disease 2019 (COVID-19): Impact on Education and Mental Health of Students and Academic Staff. Cureus, 2019(4), 4-9. https:// doi.org/10.7759/cureus.7541

Schunk, D. H., \& Pajares, F. (2005). Competence Perceptions and Academic Functioning (pp. 85104). Guilford Publications. https://psycnet.apa.org/record/2005-08058-006

Schunk, D. H., \& Zimmerman, B. J. (2007). Influencing children's self-Efficacy and selfregulation of reading and writing through modeling. Reading and Writing Quarterly, 23(1), 7-25. https://doi.org/10.1080/10573560600837578

Schunk, D. H., \& Zimmerman, B. J. (2011). Handbook of Self-Regulation of Learning and Performance (1st ed.). Rotledge. https:/ / books.google.co.id/books?id=HffFBQAAQBAJ\&printsec=frontcover\&sou $\mathrm{rce}=\mathrm{gbs} \_\mathrm{ge} \_$summary_r$\& \mathrm{cad}=0 \# \mathrm{v}=$ onepage\& $\mathrm{q} \& \mathrm{f}=$ false

Shabani, K. (2012). Dynamic assessment of L2 learners' reading comprehension processes: A Vygotskian perspective. Procedia - Social and Behavioral Sciences, 32(2010), 321-328. https://doi.org/10.1016/j.sbspro.2012.01.047

Shea, P. (2010). Online learning presence. In Proceeding of the European Distance and ELearning Network (EDEN) Annual Conference. 
Shea, P., \& Bidjerano, T. (2010). Learning presence: Towards a theory of self-efficacy, selfregulation, and the development of a communities of inquiry in online and blended learning environments. Computers and Education, 55(4), 1721-1731. https://doi.org/10.1016/j.compedu.2010.07.017

Velayutham, S., Aldridge, J., \& Fraser, B. (2011). Development and validation of an instrument to measure students' motivation and self-regulation in science learning. International Journal of Science Education, 33(15), 2159-2179. https:/ / doi.org/10.1080/09500693.2010.541529

Vicario-merino, A. (2020). iMedPub Journals in the Spanish COVID-19 Confinement Noemi Muñoz-Agustin Abstract. April, 0-6. https:/ / doi.org/10.36648/1791-809X.14.2.707

World Health Organization. (2020). WHO Director-General's opening remarks at the media briefing on COVID-19 - 11 March 2020. World Health Organization. https:/ / www.who.int/ director-general/speeches/detail/who-director-general-sopening-remarks-at-the-media-briefing-on-covid-19---11-march-2020

Zimmerman, B. J. (2002). Becoming a self-regulated learner: An overview. Theory into Practice, 41(2), 64-70. https://doi.org/10.1207/s15430421tip4102_2

Zimmerman, B. J. (2008). Investigating self-regulation and motivation: Historical background, methodological developments, and future prospects. American Educational Research Journal, 45(1), 166-183. https://doi.org/10.3102/0002831207312909 